\title{
Karyotypic Diversity Among Three Species of Garra (Family: Cyprinidae) from River Dikrong, Arunachal Pradesh, India
}

\author{
Prabhati Kumari Sahoo ${ }^{*}$, Prasanta Nanda ${ }^{2}$, and Ashoktaru Barat ${ }^{3}$ \\ ${ }^{1}$ National Research Centre for Women in Agriculture (ICAR), Khandagiri, \\ Bhubaneswar-751003, India \\ ${ }^{2}$ Dera Natung Govt. College, Itanagar-791113, Arunachal Pradesh, India \\ ${ }^{3}$ Fish Genetics \& Biotechnology Div., Central Institute of Freshwater Aquaculture, \\ Bhubaneswar-751002, India
}

Received January 26, 2007; accepted April 12, 2007

\begin{abstract}
Summary Karyotype analyses of 3 Garra species, G. gotyla gotyla (Gray), G. kempi Hora and G. lissorhynchus (McClelland) from Arunachal Pradesh, India, are presented. All the 3 species have a diploid chromosome number of $2 n=50$, but different karyotype formulae. The species-specific karyotypes were observed in the 3 species. It was also tried to draw a possible phylogenetic relationship among the 3 species.
\end{abstract}

Key words Garra, Cyprinidae, Karyotype, Phylogenetic relationship.

Garra, a genus belonged to family cyprinidae, consists of nearly about 34 species, among which 18 are available in India (Talwar and Jhingran 1992). They are widely distributed in Asia and Africa and adopted to swift flowing mountain streams using small sucking disc on the lower lip that enables the fish to hold fast in a strong current. Morphologically all species are very similar with minor variations which causes a great difficulties in proper identification, as for example, G. gravelyi, G. kempi and G. orientalis from the upper Irrawaddy river basin in Yunnan, South China (Zhang 2006). Hence, information on the cytogenetics related to chromosome number and karyotype of each species would help in species identification as also focus on their phylogenetic relationship. Cytogenetic studies in recent years gained a considerable importance, concerning species characterization, evolution and systematic (Barat et al. 2002, Gold et al. 1990). In the present studies, it was tried to characterize and to draw a relationship among the three species of Garra on the basis of their respective karyotype. This finding would help in solving the species identification.

\section{Materials and methods}

Ten live samples, (4 each for Garra gotyla gotyla, G. kempi and 2 for G. lissorhynchus, respectively) were collected from River Dikrong, near Itanagar, Arunachal Pradesh. After several trials we failed to get some more samples, hence we restricted our studies on the above nos. of sample. The initial species identification was made on the basis of morphology (Talwar and Jhingran 1992, Nath and Dey 2000).

\section{Chromosome and karyotype Analysis}

All the samples were injected intramuscularly with $1 \mathrm{ml}$ of $0.05 \%$ colchicine (Sigma,

\footnotetext{
*Corresponding author, e-mail: psahooin@yahoo.co.in
} 
US)/100 $\mathrm{g}$ of body weight and kept the fishes alive for $2-3 \mathrm{~h}$. with proper aeration. Gill and kidney tissues were processes for chromosome preparation following conventional $\mathrm{KCl}$-acetomethanolflame drying protocols (Khuda-Bukhsh and Barat 1987). The slides were stained with 4\% Giemsa stain in phosphate buffer ( $\mathrm{pH}$ 6.8). 50-60 well spread metaphase complements were obtained for each individual. The chromosomes of three well spread metaphase complements for each species were individually measured and their centromeric indices and arm ratios were determined in order to ascribe the morphology as suggested by Levan et al. (1964).

\section{Results}

The overwhelming majority of metaphase complements in the kidney and gill tissues of each species contained 50 chromosomes, though a few plates had 46 and 48 chromosomes. Therefore, the diploid number of all species under study was ascertained to be 50 . The details of each chromosome pair of each species are presented in Table 1.

Garra gotyla gotyla: The diploid metaphase complements consisted of 50 chromosomes measuring between 8.02 to $3.0 \mu \mathrm{m}$. G. gotyla gotyla showed a karyotype (Fig. 1A) formula of 12 metacentric $(\mathrm{m})+8$ submetacentric $(\mathrm{sm})+8$ subtelocentric $(\mathrm{st})+22$ telocentric $(\mathrm{T})$ with fundamental arm number (FN) as 70 .

Garra kempi: Revealed 2n=50 chromosomes, with a karyotype (Fig. 1B) formula of $14 \mathrm{M}+14 \mathrm{SM}+10 \mathrm{ST}+12 \mathrm{~T}$ and a fundamental arm number $(\mathrm{FN})$ of 78 . The size of the chromosomes varies between 10.37 to $5.0 \mu \mathrm{m}$.

Garra lissorhynchus had also diploid chromosome number as 50, but a different karyotype (Fig. 1C) of $16 \mathrm{M}+16 \mathrm{SM}+6 \mathrm{ST}+12 \mathrm{~T}$ and a fundamental arm number $(\mathrm{FN})$ of 82 . The size of the chromosomes varies between 7.62 to $3.0 \mu \mathrm{m}$.

In each karyotype the largest chromosome pair was a submetacentric (Fig. 1). That chromosome pair may be regarded as the marker chromosomes for Genus Garra.

\section{Discussion}

Out of 34 species of Garra, G. gotyla gotyla, G. lamta, G. mullya from Indian water and $G$. rufa from Turky were cytogenetically studied (Table 2). So far the authors are aware cytological work on G. kempi and G. lissorhynchus, had not been carried out earlier.

Though the cytogenetical data on G. gotyla gotyla was reported earlier (Khuda-Bukhsh and Barat 1987), but the samples were collected from different geographical localities. The karyotypes were also differing significantly though diploid chromosome number was in conformity. The variations in the chromosome formula may be an inherent in nature due to geographical isolation and possibilities of population subdivision of this species may not be ruled out. This can be confirmed by using some molecular tools taking a larger sample number.

It is also observed that except the species, G. rufa, from Turky all other species had a consistent diploid number of 50. All the species so far studied had also a species-specific pattern of karyotype with a unique largest submetacentric chromosome pair in all karyotypes. This chromosome pair can be defined as marker pair of this genus Garra and this seems to be very stable in this genus. The same pair of chromosome was also observed in the earlier reports (Khuda-Bukhsh and Barat 1987, Khuda-Bukhsh 1984, Nagpure et al. 2006, Gozukara and Cavas 2004).

In G. gotyla gotyla, more number of telocentric chromosomes were observed in comparison to other 2 species, G. kempi and G. lissorhynchus, but diploid chromosome number is same and chromosome formula is variable. This indicates that Robertsonian rearrangements as well as pericentric inversions were the main rearrangements related with the karyotype diversification of this genus Garra. It was also observed from the fundamental arm number (FN), that the 2 species, G. kempi 


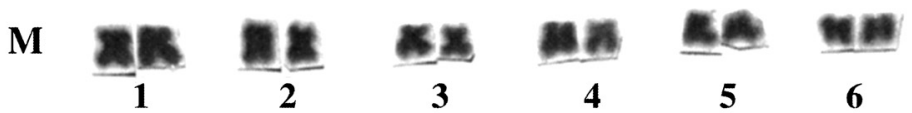

SM $\frac{16}{7} \frac{2}{8} \frac{\text { An }}{9} \frac{\mathrm{nn}}{10}$

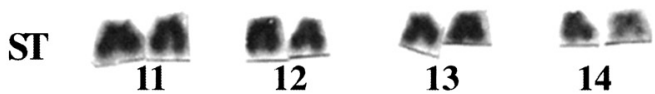

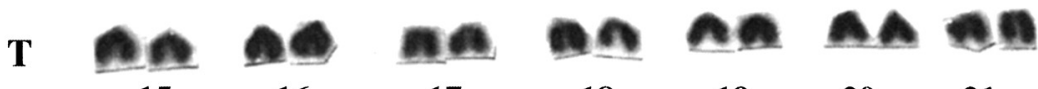

$\begin{array}{cccccccc}15 & 16 & 17 & 18 & 19 & 20 & 21 & \\ 22 & 23 & \frac{24}{24} & 25 & & & & \frac{10 \mu}{10 \mu}\end{array}$

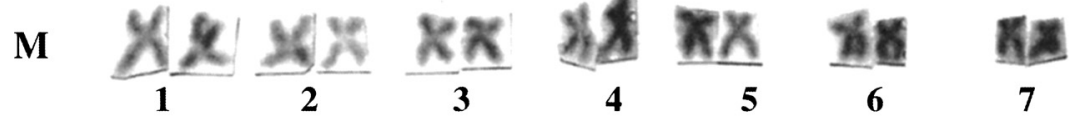

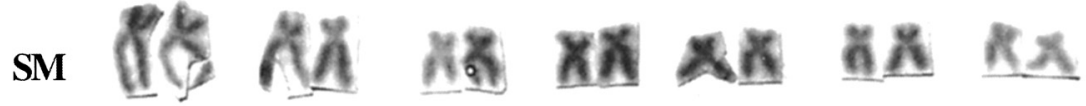
$\begin{array}{lllllll}8 & 9 & 10 & 11 & 12 & 13 & 14\end{array}$

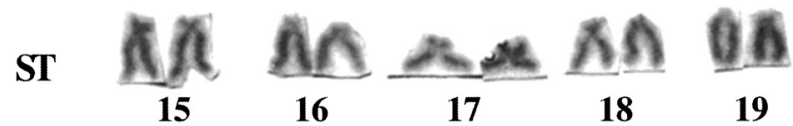

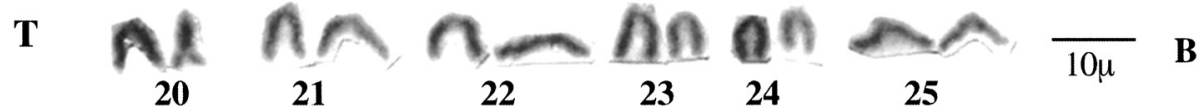

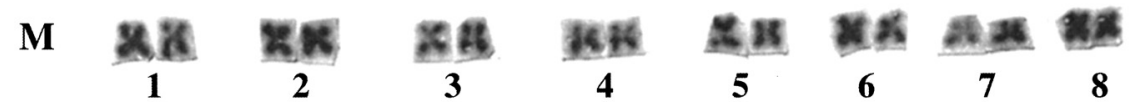

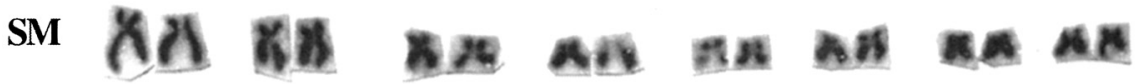

$\begin{array}{llllllll}9 & 10 & 11 & 12 & 13 & 14 & 15 & 16\end{array}$

ST an nn An.

$$
\begin{array}{lll}
17 & 18 & 19
\end{array}
$$

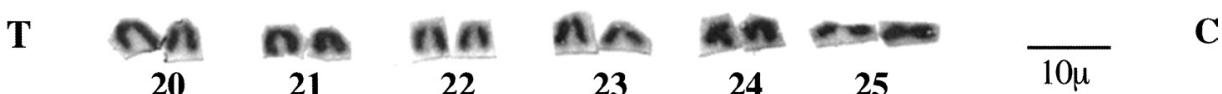

Fig. 1. A. Karyotype of G. gotyla gotyla, B. Karyotype of G. kempi, C. Karyotype of G. lissorhynchus. 
Table 1. Comparative chromosome data of three species

\begin{tabular}{|c|c|c|c|c|c|c|c|c|c|c|c|c|c|c|c|}
\hline \multirow{2}{*}{$\frac{\mathrm{SN}}{\mathrm{CN}}$} & \multicolumn{5}{|c|}{ G. gotyla gotyla } & \multicolumn{5}{|c|}{ G. kempi } & \multicolumn{5}{|c|}{ G. lissorhynchus } \\
\hline & SA & LA & $\mathrm{TL}$ & $\mathrm{AR}$ & $\mathrm{CM}$ & SA & LA & $\mathrm{TL}$ & $\mathrm{AR}$ & $\mathrm{CM}$ & SA & LA & $\mathrm{TL}$ & $\mathrm{AR}$ & $\mathrm{CM}$ \\
\hline 1 & 3.0 & 3.1 & 6.1 & 1.03 & $\mathrm{~m}$ & 3.8 & 4.2 & 8.0 & 1.1 & $\mathrm{~m}$ & 2.65 & 2.95 & 5.60 & 1.11 & $\mathrm{~m}$ \\
\hline 2 & 2.7 & 2.75 & 5.45 & 1.01 & $\mathrm{~m}$ & 2.95 & 3.5 & 6.45 & 1.18 & $\mathrm{~m}$ & 2.5 & 2.5 & 5.0 & 1.0 & $\mathrm{~m}$ \\
\hline 3 & 2.42 & 2.8 & 5.22 & 1.15 & $\mathrm{~m}$ & 2.75 & 3.5 & 6.25 & 1.27 & $\mathrm{~m}$ & 2.25 & 2.37 & 4.62 & 1.25 & $\mathrm{~m}$ \\
\hline 4 & 2.5 & 2.5 & 5.0 & 1.0 & $\mathrm{~m}$ & 2.45 & 3.65 & 6.10 & 1.48 & $\mathrm{~m}$ & 2.0 & 2.5 & 4.50 & 1.05 & $\mathrm{~m}$ \\
\hline 5 & 2.3 & 2.5 & 4.8 & 1.08 & $\mathrm{~m}$ & 2.62 & 3.12 & 5.74 & 1.19 & $\mathrm{~m}$ & 2.0 & 2.5 & 4.50 & 1.05 & $\mathrm{~m}$ \\
\hline 6 & 2.0 & 2.0 & 4.0 & 1.0 & $\mathrm{~m}$ & 2.45 & 3.0 & 5.45 & 1.22 & $\mathrm{~m}$ & 2.0 & 2.12 & 4.12 & 1.06 & $\mathrm{~m}$ \\
\hline 7 & 2.42 & 5.6 & 8.02 & 2.31 & $\mathrm{sm}$ & 1.95 & 2.2 & 4.15 & 1.12 & $\mathrm{~m}$ & 2.0 & 2.0 & 4.0 & 1.0 & $\mathrm{~m}$ \\
\hline 8 & 1.95 & 4.7 & 6.65 & 2.41 & $\mathrm{sm}$ & 3.12 & 7.25 & 10.37 & 2.32 & $\mathrm{sm}$ & 1.87 & 2.0 & 3.87 & 1.06 & $\mathrm{~m}$ \\
\hline 9 & 1.57 & 3.75 & 5.32 & 2.38 & $\mathrm{sm}$ & 2.25 & 6.25 & 8.5 & 2.77 & $\mathrm{sm}$ & 2.37 & 5.25 & 7.62 & 2.21 & $\mathrm{sm}$ \\
\hline 10 & 1.15 & 2.65 & 3.8 & 2.3 & $\mathrm{sm}$ & 2.0 & 4.95 & 6.95 & 2.47 & $\mathrm{sm}$ & 1.95 & 5.0 & 6.95 & 2.56 & $\mathrm{sm}$ \\
\hline 11 & 0.9 & 3.05 & 3.95 & 3.38 & st & 2.0 & 4.12 & 6.12 & 2.06 & $\mathrm{sm}$ & 2.0 & 4.0 & 6.0 & 2.0 & $\mathrm{sm}$ \\
\hline 12 & 0.75 & 2.95 & 3.7 & 3.93 & st & 2.0 & 4.0 & 6.0 & 2.0 & $\mathrm{sm}$ & 1.0 & 3.12 & 4.12 & 3.12 & $\mathrm{sm}$ \\
\hline 13 & 0.51 & 2.7 & 3.21 & 5.29 & st & 1.95 & 3.87 & 5.82 & 1.98 & $\mathrm{sm}$ & 1.0 & 3.0 & 4.0 & 3.0 & $\mathrm{sm}$ \\
\hline 14 & 0.45 & 2.2 & 2.65 & 4.88 & st & 1.9 & 3.62 & 5.52 & 1.90 & $\mathrm{sm}$ & 1.0 & 2.83 & 3.83 & 2.83 & $\mathrm{sm}$ \\
\hline 15 & 0.0 & 4.0 & 4.0 & $\infty$ & $\mathrm{T}$ & 1.45 & 5.87 & 7.32 & 4.04 & st & 1.27 & 2.35 & 3.62 & 1.85 & $\mathrm{sm}$ \\
\hline 16 & 0.0 & 4.0 & 4.0 & $\infty$ & $\mathrm{T}$ & 1.0 & 6.25 & 7.25 & 6.25 & st & 1.0 & 2.0 & 3.0 & 2.0 & $\mathrm{sm}$ \\
\hline 17 & 0.0 & 3.85 & 3.85 & $\infty$ & $\mathrm{T}$ & 1.65 & 5.0 & 6.65 & 3.03 & st & 0.93 & 4.0 & 4.93 & 4.32 & st \\
\hline 18 & 0.0 & 3.8 & 3.8 & $\infty$ & $\mathrm{T}$ & 0.5 & 5.25 & 5.75 & 10.5 & st & 0.98 & 3.88 & 4.86 & 3.97 & st \\
\hline 19 & 0.0 & 3.8 & 3.8 & $\infty$ & $\mathrm{T}$ & 0.62 & 4.25 & 4.87 & 6.85 & st & 1.13 & 3.75 & 4.88 & 3.33 & st \\
\hline 20 & 0.0 & 3.8 & 3.8 & $\infty$ & $\mathrm{T}$ & 0.0 & 6.25 & 6.25 & $\infty$ & $\mathrm{T}$ & 0.0 & 3.75 & 3.75 & $\infty$ & $\mathrm{T}$ \\
\hline 21 & 0.0 & 3.72 & 3.72 & $\infty$ & $\mathrm{T}$ & 0.0 & 6.25 & 6.25 & $\infty$ & $\mathrm{T}$ & 0.0 & 3.63 & 3.63 & $\infty$ & $\mathrm{T}$ \\
\hline 22 & 0.0 & 3.5 & 3.5 & $\infty$ & $\mathrm{T}$ & 0.0 & 5.78 & 5.78 & $\infty$ & $\mathrm{T}$ & 0.0 & 3.50 & 3.50 & $\infty$ & $\mathrm{T}$ \\
\hline 23 & 0.0 & 3.5 & 3.5 & $\infty$ & $\mathrm{T}$ & 0.0 & 5.75 & 5.75 & $\infty$ & $\mathrm{T}$ & 0.0 & 3.25 & 3.25 & $\infty$ & $\mathrm{T}$ \\
\hline 24 & 0.0 & 3.25 & 3.25 & $\infty$ & $\mathrm{T}$ & 0.0 & 5.0 & 5.0 & $\infty$ & $\mathrm{T}$ & 0.0 & 3.0 & 3.0 & $\infty$ & $\mathrm{T}$ \\
\hline 25 & 0.0 & 3.0 & 3.0 & $\infty$ & $\mathrm{T}$ & 0.0 & 5.0 & 5.0 & $\infty$ & $\mathrm{T}$ & 0.0 & 3.0 & 3.0 & $\infty$ & $\mathrm{T}$ \\
\hline
\end{tabular}

SN, Species name; CN, Chromosome no.; SA, Short arm; LA, Long arm; TL, Total arm; AR, arm ratio; CM, Chromosome morphology; m, metacentric; sm, submetacentric; st, subtelocentric; T, telocentric.

Table 2. Cytogenetical data of fishes under Garra

\begin{tabular}{|c|c|c|c|c|c|c|}
\hline S1. No & Species name & Locality & $2 n$ & Chromosome formula & $\mathrm{FN}$ & Authors \\
\hline 1 & G. gotyla gotyla & Itanagar, A. P & 50 & $12 \mathrm{~m}+8 \mathrm{sm}+8 \mathrm{st}+22 \mathrm{~T}$ & 70 & Present studies \\
\hline 2 & G. gotyla gotyla & Ooty, TN. & 50 & $14 \mathrm{~m}+26 \mathrm{sm}+10 \mathrm{~T}$ & 90 & $\begin{array}{l}\text { Khuda-Bukhsh and } \\
\text { Barat } 1987\end{array}$ \\
\hline 3 & G. gotyla gotyla & Jammu, J \& K & 50 & $14 \mathrm{~m}+10 \mathrm{sm}+10 \mathrm{st}+16 \mathrm{~T}$ & & Khuda-Bukhsh, 1984 \\
\hline 4 & G. kempi & Itanagar, A. P & 50 & $14 \mathrm{~m}+14 \mathrm{sm}+10 \mathrm{st}-12 \mathrm{~T}$ & 78 & Present studies \\
\hline 5 & G. lamta & & 50 & $12 \mathrm{~m}+24 \mathrm{sm}+2 \mathrm{st}+12 \mathrm{~T}$ & 86 & KhudaBukhsh et al. 1986 \\
\hline 6 & G. lissorhynchus & Itanagar, A. P & 50 & $16 \mathrm{~m}+16 \mathrm{sm}+6 \mathrm{st}+12 \mathrm{~T}$ & 82 & Present studies \\
\hline 7 & G. mullya & $\begin{array}{l}\text { Chalakkudy river, } \\
\text { Kerala }\end{array}$ & 50 & $18 \mathrm{~m}+14 \mathrm{sm}+10 \mathrm{st}+8 \mathrm{~T}$ & 82 & Nagpure et al. 2006 \\
\hline 8 & G. rufa & Turky & 44 & $22 \mathrm{~m}+20 \mathrm{sm}+2 \mathrm{~A}$ & 85 & Gozukara and Cavas, 2004 \\
\hline
\end{tabular}

and G. lissorhynchus are genetically closer than G. gotyla gotyla forming two distinct clusters, one consisted of G. gotyla gotyla and the other consisted of G. kempi and G. lissorhynchus.

\section{Acknowledgement}

The authors are grateful to The Principal, Dera Natung Govt. College, Arunachal Pradesh, for providing laboratory facilities. They also acknowledge the assistance tendered by Mr. H. Sharma, 
Asist. Professor, Dera Natung Govt College.

\section{References}

Barat, A., Sahoo, P. K. and Ponniah, A. G. 2002. Karyotype and Nucleolar Organizer Regions (NORs) in a few hill stream fishes. In: Ayyappan, S., Jena, J. K., Joseph, M. M. (eds) The Fifth Indian Fisheries Forum Proceedings, AFSIB, Mangalore and AoA, Bhubaneswar, pp. 111-114.

Gold, J. R., Li, Y. C., Shipley, N. S. and Powers, P. K. 1990. Improved methods for working with fish chromosomes with a review of metaphase chromosome banding. J. Fish Biol. 37: 563-575.

Gozukara, S. E. and Cavas, T. 2004. A karyological analysis of Garra rufa (Heckel, 1843) (Pisces, Cyprinidae) from the Eastern Mediterranean River basin in Turkey. Turk. J. Vet. Anim. Sci. 28: 497-500.

Khuda-Bukhsh, A. R. 1984. Karyotypic studies in two species of hillstream fishes, Labeo diplostomus and Garra gotyla gotyla (Pisces, Cyprinidae). In: Manna, G. K., Sinha, U. (eds) Perspectives in Cytology and Genetics, Hindasia Publishers, New Delhi, pp. 421-424.

—, and Barat, A. 1987. Chromosomes in fifteen species of Indian Teleosts (Pisces). Caryologia 40: 131-144.

—, Chanda, T. and Barat, A. 1986. Karyomorphology and evolution in some Indian hillstream fishes with particular reference to polyploidy in some species. In: Uyeno, T., Arai, R., Taniuchi, T., Matsuura, K. (eds) Indo Pacific Fish Biology: Proceedings of the Second International Conference on Indo Pacific Fishes, Ichthyological Society of Japan, Tokyo, pp. 886-898.

Levan, A., Fredga, K. and Sandberg, A. A. 1964. Nomenclature for centromeric position on chromosomes. Hereditas 52: 201-220.

Nagpure, N. S., Kumar, R., Srivastava, S. K., Gopalakrishnan, A., Basheer, V. S. and Kapoor, K. 2006. Cytogenetic studies of two cyprinids Garra mullya and Barilius bakeri from the Western Ghats of India. J. Cytol. Genet. 7: 69-78.

Nath, P. and Dey, S. C. 2000. Fish and Fisheries of North Eastern India (Arunachal Pradesh). Narendra Publishing House, Delhi.

Talwar, P. K. and Jhingran, A. G. 1992. Inland Fishes of India and adjacent countries. Vol. 1\&2. Oxford and IBH Publishing Co. New Delhi.

Zhang, E. 2006. Garra rotundinasus, a new species of cyprinid fish (Pisces: Teleostei) from the upper Irrawaddy river basin, China. The Raffles Bull Zool 54: 447-453. 